\title{
The Entry Risk of Chinese State-owned Companies in Direct Investment in South Africa
}

\author{
Xin Wen \\ Big Data Applications and Faculty of Economics, Guizhou University of Finance and Economics, Guiyang, \\ China
}

Keywords: South Africa; Business environment; Chinese state-owned enterprise; Infrastructure industries; Direct investment

\begin{abstract}
China's direct investment in South Africa in recent years has been mainly completed by state-owned enterprises. The state-owned nature of these multinational investment companies at a glance has begun to attract the attention and vigilance of the South Africa government and local Stockholders, including local unions. It has affected the approval of Chinese companies' investment in South Africa in the next step. And furthermore, it has made those business opportunities abroad unpredictable.
\end{abstract}

\section{Introduction}

The obvious lower welfare conditions of labor of Chinese farmers and black South Africans dramatically formed, gradually during decades, a favorable advantage for accelerating the original accumulation of private capital in a globalized market system. Lacking collective bargaining ability due to the lack of unions, naturally, has been forcing those labors to endure relatively low wages and little welfare. There is a very similar comparable advantage forming process by mass of Chinese non-urban peasant farmers and South African incoming black. Together with comprehensive local division of labor network, it constitutes the best investment environment of manufacturing industries in the world.

By the end of 2018, South African companies had accumulated a total of $\$ 774$ million in direct investment in China. As the most important African partner, South Africa, attributed in China the largest investment proportion of African countries overall. Chinese investors have gradually increased their enthusiasms for investing in South Africa in recent years [1].

A rising problem occurred, naturally, do South Africa have a suitable business environment for Chinese companies? Why Chinese state-owned companies mainly invested only in infrastructures? And finally, will there be a capital flight in South Africa in the future?

\section{Characteristics of the South Africa's Business Environment}

According to the 2020 business Environment Report released by the World Bank on May 8, 2019, China ranked 31st in the business environment rankings, while South Africa, another BRICS country, ranked only 84th. This fact reveals that China and South Africa have a considerable gap in the business environment. The following figures (Figures 1 and 2) attempts to analyze what concrete risks China's direct investment in South Africa may face. The ordinate points to the scores of every item of business environment.

South Africa's Direct General of Foreign Affairs Anil Sukraal said the benefits of the "Belt and Road" initiative to Africa should not be limited to building infrastructure projects such as railways, bridges, etc. [2]. 


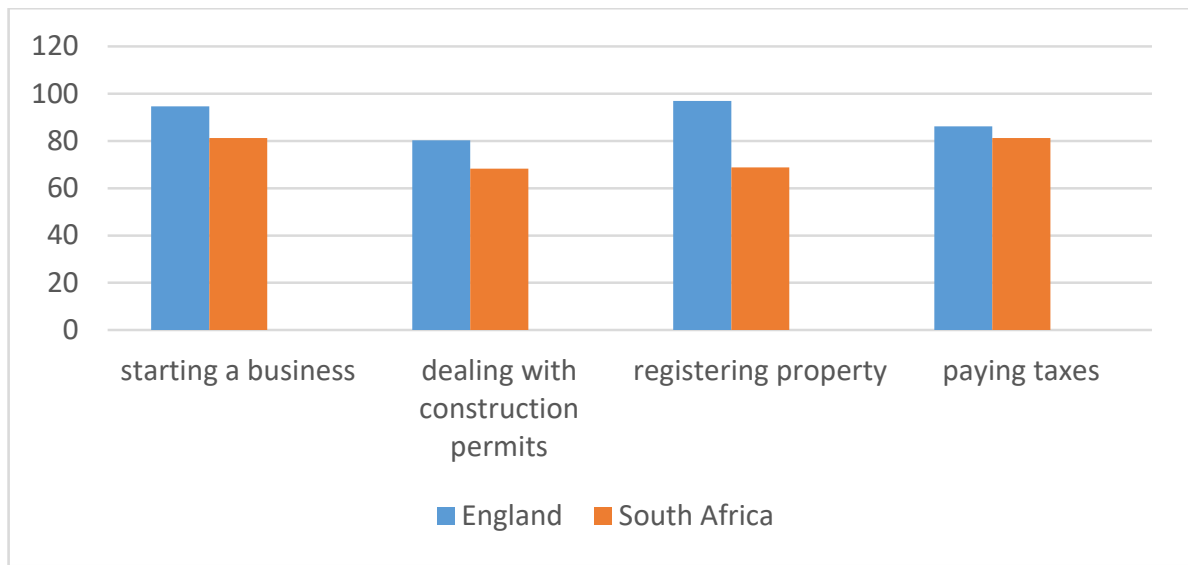

Figure 1 Comparison of four items of business environment. Source: doingbusiness.org (measuring business regulation, May 2019)

The question here is, why does Chinese state-owned enterprise have mysterious fear and hesitation towards other industries in South Africa? What unpredictable risks would Chinese Stateowned enterprises worry about if cross-border investments are put into South Africa's industry other than infrastructure projects?

\section{Why Chinese state-owned companies mainly invested only in infrastructures?}

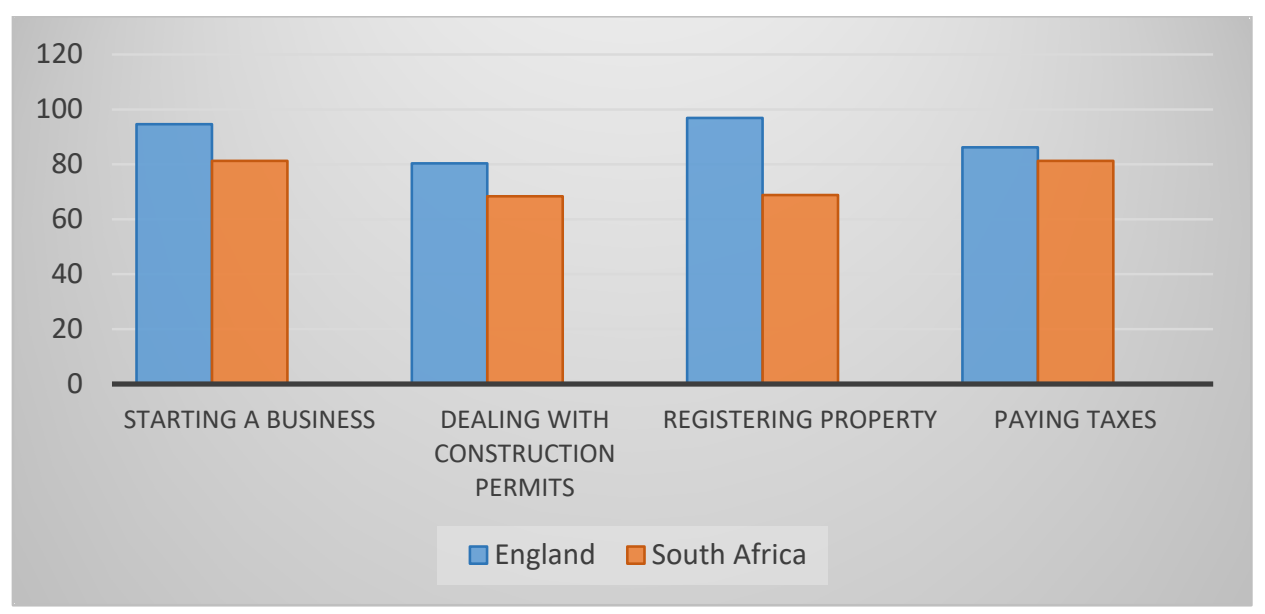

Figure 2 Comparison of the latter four items of business environment. Source: doingbusiness.org (measuring business regulation, May 2019)

The above Figure 2 explains why the entry risk is enormous when Chinese state-owned enterprises compared with other types of private companies will play this role of investing other industries except infrastructures. The ordinate points to the scores of every item of business environment.

The registering property score is obviously low according to Figure 2, which means private property faces uncertainty in the program of registering [3]. But the infrastructure has little need for registering concrete property, that is belonging to the whole country, even to say, the government's. That effectively escape the registering process.

Corruption in various projects in South Africa may cause foreign direct investment suffer losses. In the field of infrastructures, Chinese Companies experienced corruption in infrastructure projects in South Africa, including unscientific assessments, unreasonable pricing, too-low returns and toolong bid evaluation process [4]. Chinese companies suspect these phenomenon will happen in all kinds of industries in South Africa [5].

In the following Table I, the score of the item of dealing with construction permit in South Africa is only 68.3, much lower than England. As concerned with the item of resolving insolvency, the score distance is much bigger. 
Table 1 Comparison of Each Score of the Convenience of the Business Environment between the United Kingdom and South Africa

Source: doingbusiness.org (measuring Business Regulation, May 2019)

\begin{tabular}{c|c|c}
\hline & The United Kingdom & South Africa \\
\hline Starting a business & 94.6 & 81.2 \\
\hline Dealing with construction permits & 80.3 & 68.3 \\
\hline Getting electricity & 96.9 & 68.8 \\
\hline Registering property & 75.7 & 59.5 \\
\hline Getting Credit & 75.0 & 60.0 \\
\hline Paying taxes & 86.2 & 81.2 \\
\hline Trading across borders & 93.8 & 59.6 \\
\hline Enforcing contracts & 68.7 & 56.9 \\
\hline Resolving insolvency & 80.3 & 54.6 \\
\hline
\end{tabular}

\section{Will the Degrading of Ease of Doing Business Trigger Capital Flight?}

Although among many driving factors behind the cross-border movement of capital, the state of the business environment has not been valued by scholars, there are few scholars, such as Zahra Dehghan (2019), targeting Southeast Asian countries as old examples of capital outflows caused by gradual degrading of ease of doing business [6].

The business environment, measured by ease of doing business, is actually an institutional variable that defines the rules of business competition in a country or a region.

The inappropriate business environment has greatly increased the transaction costs of transnational direct investment. When the business environment of a country is deteriorating individuals and institutional investors will consider investing in other economies, which can lead to capital flight [7].

Capital flight is a kind of capital outflow that originates from some kind of negative impact and will damage national welfare [8]. Then, in recent years, South Africa's business environment has been deteriorating due to political and corruption risks [9]. Could it be the prelude to the negative impact of the capital outflow in the future?

Based on this, is it possible that China's direct investment in South Africa will face the risks of capital flight in the next decade?

\section{Conclusion}

Based on this, then, if Chinese State-owned enterprises invest in South Africa as a state-owned company, it will attract the attention of local governments and stockholders, and when an investment dispute occurs, it will cause a strong protectionist tendency because they realized clearly that investment points to the strategic asset of South Africa. South Africa is worried about the loss of the long-term national resources.

\section{References}

[1] Y. B. Hao, “Risk identification and control of Chinese enterprises' investment in South Africa”, Regional Economic Review, 2019, 6.

[2] South African Experts: “One Belt One Road” Initiative contributes to Africa's economic development and global stability, Chinese Industry and economy, 5.

[3] B. Smit, C. Grobler, and C, Nel, "Sudden Stops and current account reversals: Potential macroeconomic consequences for South Africa”, South African Journal of Economics, vol. 82, no. 4, December 2014.

[4] Y. D. Yu, L. S. Xiao, “Analysis on China’s capital flight”, International Economic Review, vol. 5, pp. 97-115, 2017. 
[5] Y. B. Hao, Y. Yin, "Risks Identification and Control of Chinese Enterprises' Foreign Direct Investment in South Africa”, Regional Economic Review, 2019, 6.

[6] Y. Lin, C. L. Chen, “Investor protection and the practice of China”, People’s Publishing House, October, first edition, 2008.

[7] N. N. Zhang, H. Zhang, B. Yang, "Institutional Risk in Countries along “One Belt One Road” and Choice of Enterprises Oversea Market Entry Mode: Empirical Research of Chinese Equipment Manufacturing Listed Companies, vol. 10, pp. 119-123, 2019.

[8] Z. D. Shabani, S. parang, “The effect of Ease of Doing Business on Capital Flight: Evidence from East Asian Countries, Iran. Econ. Rev, vol. 23, no. 4, pp. 819-838, 2019.

[9] L. Pepall, D. Richards, and G. Norman, "Industrial Organization: Contemporary Theory and Empirical Applications (4th Edition)”, China Renmin Universtiy Press, 2014, pp. 601-609. 